\title{
A Sensitive Aptamer-Based Biosensor for Electrochemical Quantification of PSA as a Specific Diagnostic Marker of Prostate Cancer
}

\author{
Shokoufeh Hassani ${ }^{1}$, Armin Salek Maghsoudi ${ }^{1}$, Milad Rezaei Akmal $^{2}$, Soheila Rahmani ${ }^{1}$, \\ Pouria Sarihi ${ }^{1}$, Mohammad Reza Ganjali ${ }^{2,3}$, Parviz Norouzi ${ }^{2,3}$, Mohammad Abdollahi ${ }^{1,3 *}$ \\ ${ }^{1}$ Toxicology and Diseases Group (TDG), Pharmaceutical Sciences Research Center (PSRC), The Institute of Pharmaceutical \\ Sciences (TIPS), and Department of Toxicology and Pharmacology, School of Pharmacy, Tehran University of Medical \\ Sciences, Tehran, Iran. ${ }^{2}$ Center of Excellence in Electrochemistry, Faculty of Chemistry, University of Tehran, Tehran, Iran. \\ ${ }^{3}$ Endocrinology and Metabolism Molecular-Cellular Sciences Institute, Tehran University of Medical Sciences, Tehran, Iran.
}

Received, June 1, 2020; Revised, July 5, 2020; Accepted, July 6, 2020; Published, July 8, 2020.

\begin{abstract}
Purpose: The current project aimed to design a simple, highly sensitive, and economical label-free electrochemical aptasensor for determination of prostate-specific antigen (PSA), as the gold standard biomarker for prostate cancer diagnosis. The aptasensor was set up using a screen-printed carbon electrode (SPCE) modified by gold nanoparticles ( $\mathrm{Au} \mathrm{NPs)} \mathrm{conjugated} \mathrm{to} \mathrm{thiolated} \mathrm{aptamers.} \mathrm{Methods:} \mathrm{Cyclic} \mathrm{voltammetry} \mathrm{(CV)} \mathrm{and}$ electrochemical impedance spectroscopy (EIS) were implemented for electrochemical (EC) characterization of the aptasensor. The determination of PSA was also performed through differential pulse voltammetry (DPV) in [Fe (CN) 6] ${ }^{3-14-}$ electrolyte solution. Results: The present aptasensor was shown an outstanding linear response in the concentration range of $1 \mathrm{pg} / \mathrm{mL}-200 \mathrm{ng} / \mathrm{mL}$ with a remarkably lower limit of detection of $0.077 \mathrm{pg} / \mathrm{mL}$. The optimum concentration for PSA separation and the optimum incubation time for antigen-aptamer binding were determined by observing and electing the highest electrochemical responses in a specified time or concentration. Conclusion: According to the results of the specificity tests, the designed aptasensor did not show any significant interactions with other analytes in real samples. Clinical functionality of the aptasensor was appraised in serum samples of healthy individuals and patients examining the PSA level through the fabricated aptasensor and the reference methods. Both methods are comparable in sensitivity. The present fabricated PSA aptasensor with substantial characteristics of ultrasensitivity and cost-effectiveness can be conventionally built and used for the routine check-up of the men for prostate problems. Keywords: diagnosis, cancer, electrochemical aptasensor, gold nanoparticles, prostate-specific antigen.
\end{abstract}

\section{INTRODUCTION}

Prostate cancer is the second most predominant cancer in men and the fifth leading cause of death worldwide (1). Despite its highest 5-survival rate in all stages among cancers, its later stages are powerfully lethal and usually severe to be cured $(2,3)$. According to the evidence, prostate cancer is bound to cause no signs or symptoms at early stages, and thus early diagnosis seems necessary for treatment. Currently, prostatespecific antigen (PSA), a $34 \mathrm{kDa}$ single-chain glycoprotein, is regarded as the gold standard biomarker for the diagnosis of prostate cancer (4). It is produced by both healthy and malfunctioning prostate cells; however, the rising serum levels above four $\mathrm{ng} / \mathrm{mL}$ could be associated with prostate malignancies (5).

To date, several analytical assays, including fluorescence techniques have been investigated for the determination of PSA, such as immunechromatography tests (6-9), surface Plasmon resonance (10) surface-enhanced Raman scattering
(SERS) (11), chemiluminescence (12), Electrochemiluminescence, field-effect transistors (13), mass spectrometry (14), and electrochemical techniques (15). Nevertheless, the most common clinical methods are still amplified luminescent proximity homogeneous assay-linked immunoassay (AlphaLISA) and enzyme-linked immunosorbent assay (ELISA) (16, 17). Despite their well-known merits, AlphaLISA and ELISA suffer some manifest disadvantages painstaking analysis procedure, high-priced chemicals, and the necessity of labeling antibodies with chemiluminescent, fluorescent or enzymatic materials which make these assays less satisfactory for clinical measurements $(18,19)$.

Therefore, the implementation of alternative strategies with such high sensitivity and specificity, like aptamers, can be of utmost importance.

Corresponding Author: Prof. Mohammad Abdollahi, The Institute of Pharmaceutical Sciences (TIPS) and School of Pharmacy, Tehran University of Medical Sciences, Tehran, Iran. E-mail: Mohammad@TUMS.Ac.Ir 
With their exclusive features such as unique stability in extreme conditions of $\mathrm{pH}$ and temperature and userfriendly pretreatment, aptamers have become superior to antibody-based assays $(20,21)$. Aptamers are single-stranded DNAs or RNAs selected by a technology called SELEX (Systematic Evolution of Ligands by Exponential Enrichment). They are readily accessible but can be manufactured straightforwardly $(22,23)$. Besides their high specificity and dynamic binding towards corresponding targets, aptamers can be effortlessly modified through the incorporation of a wide range of functional substitutes, making them suitable for a variety of applications $(20,24)$. Generally, biosensorbased determination methods with their substantial selectivity and cost-effectiveness can offer reliable alternatives to the conventional analytical assays (25). In Table 1 , the characteristics of the routine assays (ELISA) and biosensing techniques for the determination of PSA have been compared. A biosensor is typically composed of the biological sensing element and a transducer $(26,27)$, which is divided into three categories: electrochemical, physical, and optical (28). The electrochemical (EC) biosensor was chosen and applied in the present study because of relatively low cost, miniaturization capacity, exceptional sensitivity, and less timeconsuming determination process (25). As for the electrical conductor, a screen-printed carbon electrode (SPCE) is selected due to its reproducible results with a small volume of sample needed for each measurement and feasibility for large scales of production $(29,30)$. On account of the advantages of aptamers compared to antibodies, which was mentioned earlier, and the fact that specific aptamers for PSA have been sequenced previously, specific thiol functionalized aptamers are employed as receptors $(19,20,31)$. The surface modification is carried out using gold nanoparticles (Au NP) to provide a larger electroactive surface area and achieve quicker and more selective analytical responses (32, 33). Herein, we report on the development of a novel label-free electrochemical aptasensor based on aptamer conjugated Au NP-modified SPCE, which can offer accurate, reproducible, and highly sensitive determination of minimum levels of PSA in clinical serum samples.

\section{METHODS}

\section{Materials}

Thiolated PSA aptamer with the following sequences based on previous studies (34) (5'-Thiol - $\left(\mathrm{CH}_{2}\right)_{6}$-TTT
TTA ATT AAA GCT CGC CAT CAA ATA GCT TT3') was synthesized by MWG-BIOTECH, Germany. Analytical reagent grades of chemicals sulfuric acid $\mathrm{H}_{2} \mathrm{SO}_{4}$, tris (2-carboxyethyl) phosphine hydrochloride (TCEP), phosphate-buffered saline (PBS), 6-mercapto-1-hexanol (MCH) gold chloride trihydrate $\left(\mathrm{HAuCl}_{4} .3 \mathrm{H}_{2} \mathrm{O}\right)$, potassium ferricyanide $\left(\mathrm{K}_{3}\left[\mathrm{Fe}(\mathrm{CN})_{6}\right]\right)$ and potassium ferrocyanide $\left(\mathrm{K}_{4}\left[\mathrm{Fe}(\mathrm{CN})_{6}\right]\right)$, monosodium phosphate $\left(\mathrm{NaH}_{2} \mathrm{PO}_{4}\right)$, disodium phosphate $\left(\mathrm{Na}_{2} \mathrm{HPO}_{4}\right)$, phosphoric acid $\left(\mathrm{H}_{3} \mathrm{PO}_{4}\right)$, sodium hydroxide $(\mathrm{NaOH})$, and bovine serum albumin (BSA) were supplied by SigmaAldrich (Germany). Prostate-specific antigen (PSA) was obtained from AdipoGen Life Sciences (Germany). Solutions were prepared using ultrapure water with a resistance of $18 \mathrm{M} \Omega . \mathrm{cm}$. The stock solution of aptamer $(20 \mu \mathrm{M})$ was prepared in the PBS $(0.1 \mathrm{M}, \mathrm{pH} 7.4)$ and stored at $-20^{\circ} \mathrm{C}$. Clinical serum samples were collected from consenting individuals from Firoozgar Hospital (Tehran, Iran). The protocol of the project was approved by the Institute Ethics Committee (IR.TUMS.VCR.REC.1398.610) and conducted following TUMS ethical principles for medical research involving human subjects.

\section{Apparatus}

To carry out the electrochemical analysis, an AUTOLAB PGSTAT 101 potentiostat/galvanostat (Methrohm Autolab BV, Utrecht, Netherlands), compatible with NOVA 2.1 software was employed. Characterization of modified-SPCEs was performed in $0.1 \mathrm{M}$ PBS (pH 7.4) containing $\left[\mathrm{Fe}(\mathrm{CN})_{6}\right]^{3-/ 4-} / \mathrm{KCl}(5$ $\mathrm{mM} / 0.1 \mathrm{M}$ ) electrolyte solution as a redox probe using three distinct EC techniques cyclic voltammetry $(\mathrm{CV})$, electrochemical impedance spectroscopy (EIS), and differential pulse voltammetry (DPV). EIS was carried out through an AC (alternating current) voltage amplitude modulation of $+10 \mathrm{mV}$ with frequency ranging between $100 \mathrm{mHz}$ and $100 \mathrm{kHz}$. CV technique was conducted to assess the procedure of fabrication of the aptasensor. The potential was calculated in the range between -0.4 and $+0.7 \mathrm{~V}$ at a scan rate of 0.1 $\mathrm{V} / \mathrm{s}$. DPV method was used under experimental conditions of potential ranging from $+0.7 \mathrm{~V}$ to $-0.4 \mathrm{~V}$, and amplitude modulation of $0.05 \mathrm{~V}$. Following electrodeposition procedure, the morphology of $\mathrm{Au}$ NPs was thoroughly assessed by FESEM (Hitachi S4160, Japan). SPCEs (DropSens, Spain) measuring 3.4 $\times 1.0 \times 0.05 \mathrm{~cm}$ (length $\times$ width $\times$ height $)$ were made up of carbon working, carbon counter, and silverbased reference electrodes. 


\section{Au NP-modified SPCEs assembly}

Surface modification of the working electrode interface was carried out by $\mathrm{Au}$ NP electrodeposition, using a solution of $10 \mathrm{mM} \mathrm{HAuCl} \mathrm{H}_{4} .3 \mathrm{H}_{2} \mathrm{O}$ in $0.5 \mathrm{M}$ $\mathrm{H}_{2} \mathrm{SO}_{4}$. Firstly, the electrode surface was activated by a $0.5 \mathrm{M} \mathrm{H}_{2} \mathrm{SO}_{4}$ solution. Prior to the activation, the SPCE was characterized via CV measurements in the range between -0.4 and $+0.7 \mathrm{~V}$ in $0.1 \mathrm{M}$ PBS ( $\mathrm{pH} 7.4$ ) containing $\left[\mathrm{Fe}(\mathrm{CN})_{6}\right]^{3-/ 4-} / \mathrm{KCl}(5 \mathrm{mM} / 0.1 \mathrm{M})$ electrolyte solution as the electrochemical redox probe with scan rate of $0.1 \mathrm{~V} / \mathrm{s}$. After activation of the electrode, the $\mathrm{Au}$ NPs were electrodeposited under optimal conditions of the potential of $-0.2 \mathrm{~V}$ in a medium of $\mathrm{HAuCl}_{4} / \mathrm{H}_{2} \mathrm{SO}_{4}(10 \mathrm{mM} / 0.5 \mathrm{M})$ for $80 \mathrm{~s}$. The efficiency of electrodeposition was assessed through CV measurements, and then the voltammograms of Au NP- modified SPCE and bareactivated SPCE were compared. Finally, the deposition of Au NPs on SPCE was confirmed by using FESEM.

\section{Aptamer immobilization onto Au NPs /SPCEs surface}

To modify the electrode surface by immobilized bioreceptor, the stock solution of PSA aptamer (20 $\mu \mathrm{M})$ was reduced with a $10 \mathrm{mM}$ TCEP solution for one $\mathrm{h}$ at $25^{\circ} \mathrm{C}$ to break disulfide bonds. Subsequently, the stock solution of PSA aptamer was diluted with a ratio of 1:20 with $0.1 \mathrm{M}$ PBS ( $\mathrm{pH}=7.4)$. Afterward, $10 \mu \mathrm{L}$ of aptamer solution $(1 \mu \mathrm{M})$ was dropped onto the $\mathrm{Au}$
NPs-modified SPCE following a $12 \mathrm{~h}$ dark incubation at $4{ }^{\circ} \mathrm{C}$, which resulted in the formation of selfassembled monolayers (SAM). At the end of the incubation period, the SPCE was thoroughly rinsed with ultrapure water to ensure the removal of any free aptamers. Remaining active binding sites were blocked by adding the MCH solution ( $1 \mathrm{mM})$. After 30 min incubation, modified SPCE was again rinsed with ultrapure water, and the electrode was dried under a stream of $\mathrm{N}_{2}$ gas.

\section{Electrochemical determination of PSA}

After immobilizing aptamers on modified SCPE, PSA solution at different concentrations was added on the obtained modified electrodes (MCH/aptamer/Au $\mathrm{NPs} / \mathrm{SPCEs}$ ). Following $45 \mathrm{~min}$ incubation at $25^{\circ} \mathrm{C}$, the electrodes were washed using ultrapure water and dried under a stream of $\mathrm{N}_{2}$ gas. The aptasensor was then placed into an electrochemical cell filled with 0.1 M PBS $(\mathrm{pH}=7.4)$ containing $\left[\mathrm{Fe}(\mathrm{CN})_{6}\right]^{3-4-} / \mathrm{KCl}(5$ $\mathrm{mM} / 0.1 \mathrm{M}$ ) electrolyte solution. The DPV signals of $\mathrm{PSA} / \mathrm{MCH} /$ thiolated aptamer/Au NPs/ SPCEs were measured and recorded in different concentrations of PSA under the experimental condition of potential ranging between +0.7 and $-0.4 \mathrm{~V}$, interval time of 0.2 $\mathrm{s}$ and modulation time of $0.05 \mathrm{~s}$. The procedure of electrochemical aptasensor development is illustrated in Scheme 1.

Table 1. Comparison of ELISA and biosensing techniques for the determination of tumor markers.

\begin{tabular}{lll}
\hline \multicolumn{1}{c}{ Techniques } & \multicolumn{1}{c}{ Conventional method (ELISA) } & \multicolumn{1}{c}{ Electrochemical Aptasensor } \\
\hline Biorecognition element & $\begin{array}{l}\text { An antibody is expensive and needs } \\
\text { complex reactors } \\
\text { Storage: Needs to freeze }\end{array}$ & $\begin{array}{l}\text { An aptamer is inexpensive and } \\
\text { chemically synthesized. } \\
\text { Storage: Stable at room temperature }\end{array}$ \\
$\begin{array}{lll}\text { Sample preparation and } \\
\text { reagent }\end{array}$ & $\begin{array}{l}\text { More organic solvent consumption, higher } \\
\text { sample volume, more reagent, and higher- } \\
\text { cost }\end{array}$ & $\begin{array}{l}\text { Less organic solvent consumption, } \\
\text { lower sample volume, less reagent, } \\
\text { and lower cost }\end{array}$ \\
& Centralized laboratories with experienced & Portability and no expertise required \\
Analysis and application & personnel & \\
& Time-consuming & Rapid real-time determination \\
Assay time & Matrix interface problem & High selectivity and specificity \\
Specificity and selectivity & fossible false positive/negative results & Inexpensive \\
\hline
\end{tabular}




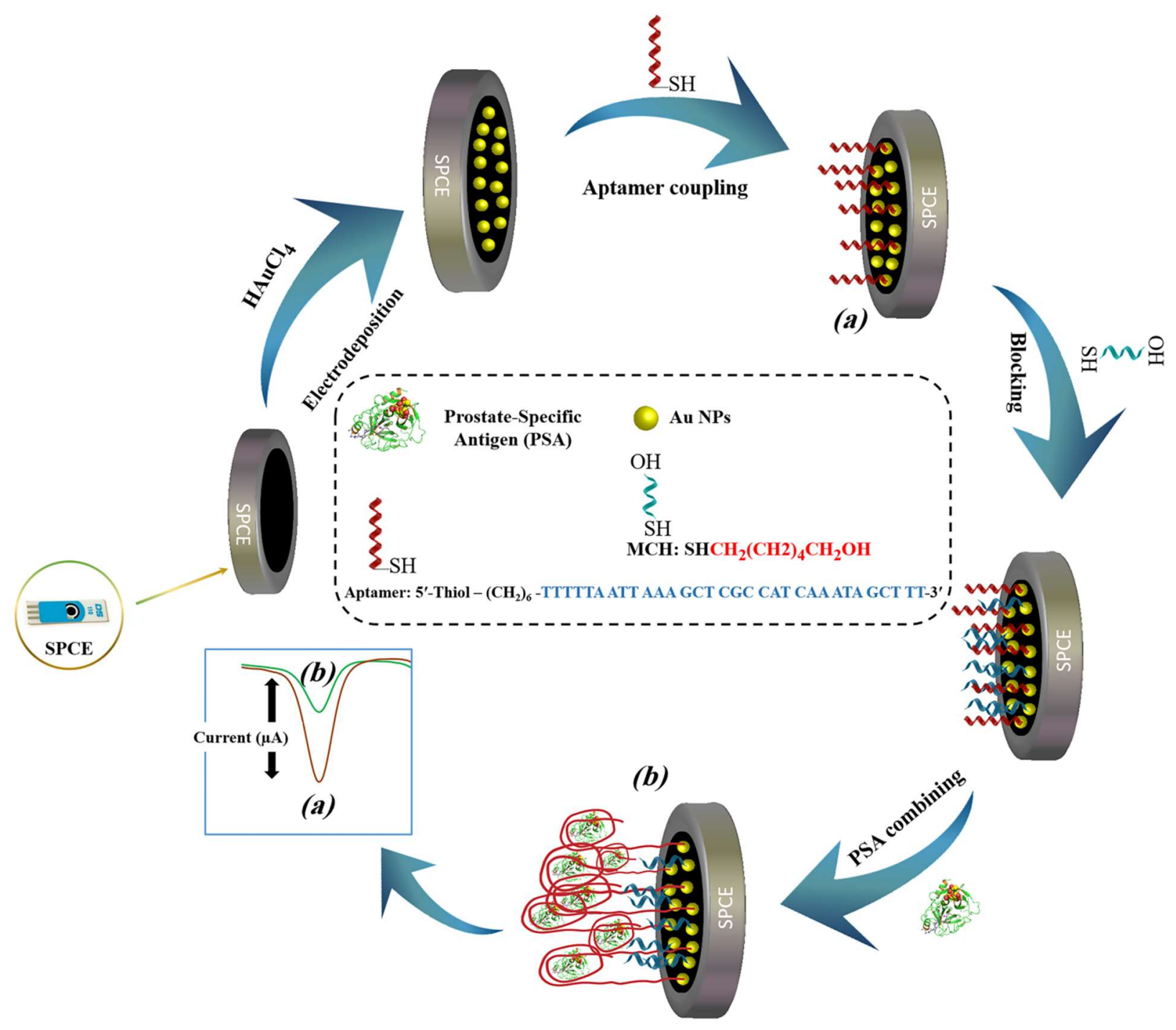

Scheme 1. Schematic illustration of PSA assay based on the electrochemical technique.

\section{RESULTS AND DISCUSSION}

\section{Characterization of the Au NPs}

Figures $1 \mathrm{~A}$ and $1 \mathrm{~B}$ depict the FESEM images of untreated and $\mathrm{Au}$ NPs-modified SPCEs. Signal transduction was substantially enhanced by exploiting $\mathrm{Au}$ NPs, which successfully expanded the SPCE's electroactive surface area and increased the number of immobilized thiolated aptamers (35).

Activation by $\mathrm{CV}$ was performed in $\mathrm{H}_{2} \mathrm{SO}_{4}$ solution $(0.5 \mathrm{M})$ with potential ranging between -0.1 and $1.3 \mathrm{~V}$ and a scan rate of $0.1 \mathrm{~V} / \mathrm{s}$ to achieve steady and repetitive voltammograms. Recent studies suggest that the elimination of the oxide layer and the introduction of the highly active sites on the electrode surface after activation may lead to a significant improvement in electrochemical performance (36). Characterization of the SPCE was conducted by CV (0.4 to $+0.7 \mathrm{~V}$ ) with scan rates of $0.1 \mathrm{~V} / \mathrm{s}$ in $0.1 \mathrm{M} \mathrm{PBS}$ $(\mathrm{pH}=7.4)$ containing $\left[\mathrm{Fe}(\mathrm{CN})_{6}\right]^{3-/ 4-/ \mathrm{KCl}}(5 \mathrm{mM} / 0.1$ $\mathrm{M})$ electrolyte solution as the electrochemical redox probe. Following activation of the electrode, deposition capacity, and the size of Au NPs coated on the SPCE could be crucially affected by the time of deposition $(37,38)$. To obtain the maximum electrochemical response, the deposition time of $\mathrm{Au}$ NPs was fixed at $80 \mathrm{~s}$, and CV measurements were subsequently conducted on Au NPs modified and 
solely activated SPCEs in the solution of $0.1 \mathrm{M}$ PBS ( $\mathrm{pH} 7.4$ ) containing $\left[\mathrm{Fe}(\mathrm{CN})_{6}\right]^{3-/ 4-/} \mathrm{KCl}(5 \mathrm{mM} / 0.1 \mathrm{M})$.

\section{Label-free aptasensor (PSA/MCH/ thiolated aptamer/ Au NPs /SPCEs) characterization}

Characterization of the PSA/thiolated aptamer/Au NPs/SPCEs was performed separately through EIS and CV to monitor each step involved in assembly processes. The whole process was carried out in $0.1 \mathrm{M}$ PBS (pH 7.4) containing $\left[\mathrm{Fe}(\mathrm{CN})_{6}\right]^{3-/ 4-} / \mathrm{KCl}(5 \mathrm{mM} /$ $0.1 \mathrm{M}$ ) electrolyte solution (39).

$\mathrm{CV}$ measurements were recorded over a potential range between -0.4 and $+0.7 \mathrm{~V}$ with a scan rate of 0.1 $\mathrm{V} / \mathrm{s}$. Figure 2 shows the redox probe $\mathrm{CV}$ scans of the bare SPCE (curve a), Au NPs/SPCE (curve b), aptamer/Au NPs/SPCE (curve c), MCH/aptamer/Au NPs /SPCE (curve d) and $1 \mathrm{ng} / \mathrm{mL}$ PSA/aptamer/Au NPs/SPCE (curve e). To demonstrate the process of EC aptasensor fabrication, $\mathrm{CV}$ and EIS techniques were applied. The functional properties of the redox probe were investigated in various stages with different current response values and peak-to-peak separations $(\Delta \mathrm{Ep}=$ Epa-Epc $)$.

Regarding its fast heterogeneous electron transfer features, bare carbon SPE showed appropriate reversible peaks. The characteristics of $\left[\mathrm{Fe}(\mathrm{CN})_{6}\right]^{3-/ 4-}$ were evaluated, measuring redox peak separation and calculating $\Delta \mathrm{Ep}$ of the cathodic and anodic waves and current responses. According to Figure 2 curve a, the $\mathrm{CV}$ records of the redox probe at the SPCE indicated a pair of reversible reduction/oxidation peak $\left(\Delta \mathrm{E}_{\mathrm{P}}\right.$ $215.78 \mathrm{mV}$ ). After modifying the electrode with $\mathrm{Au}$ $\mathrm{NPs}$, a decrease of $\Delta \mathrm{E}_{\mathrm{P}}$ to $(173.34 \mathrm{mV})$ and an increase of the oxidation peak current was observed (Figure 2, curve b), which can be ascribed to the electrocatalytic activity, good conductivity and larger exposed area of $\mathrm{Au}$ NPs. Self-assembly of the thiolated aptamer onto the Au NP SPCE led to a significant fall in the peak current of redox probe $\left[\mathrm{Fe}(\mathrm{CN})_{6}\right]^{3-/ 4-}$ and a corresponding rise in $\Delta \mathrm{E}_{\mathrm{P}}(202.87 \mathrm{mV})$ (Figure 2, curve $\mathrm{c}$ ). This phenomenon could be associated with the repulsive steric hindrance of the negatively charged phosphate groups of the aptamer hampering the electrolyte transfer. Figure 2, curve d represents the $\mathrm{MCH}$ added onto the electrode surface for the blockade of non-specific sites, which caused a marked decline in the redox peak current and a similar rise in the peak separation $(\Delta \mathrm{Ep} 250.40 \mathrm{mV})$. Lastly, the peak current value underwent a noticeable decrease after the reaction of the aptasensor with PSA solution (1 $\mathrm{ng} / \mathrm{mL}$ ), and the peak potential separation was raised correspondingly ( $\Delta \mathrm{Ep} 278.32 \mathrm{mV}$ ) (Figure 2, curve e). This may be ascribed to the steric hindrance resulting from the conjunction of DNA aptamer and PSA, which closely correlated with the concentration of PSA solution; the higher the extent of PSA, the more significant the decrease in the peak current would be (23).

\section{Optimization of the analytical parameters for PSA determination}

Various parameters such as Au NPs deposition time, aptamer concentration, aptamer self-assembly time, and incubation time were optimized to boost the performance of the aptasensor. The CV measurements of the EC aptasensor were carried out at different deposition time of Au NPs treatment (Figure 3).



Figure 1. FESEM images of unmodified SPCE (A) and modified (Au NPs) SCPE (B) using electrodeposition method (10 mM $\mathrm{HAuCl}_{4}$ in $0.5 \mathrm{M} \mathrm{H}_{2} \mathrm{SO}_{4}$; time: $80 \mathrm{~s}$ ). 


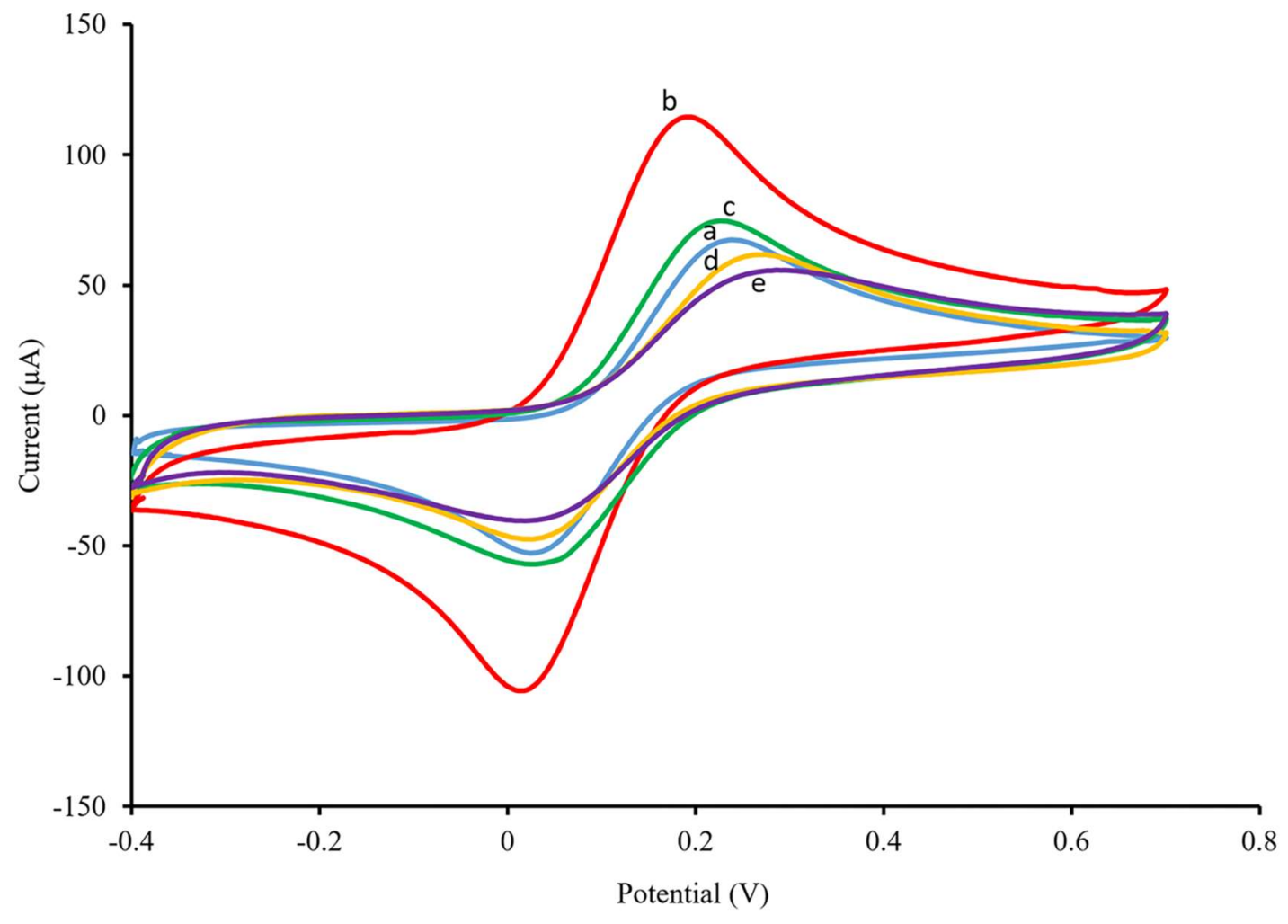

Figure 2. CV plots of the untreated SPCE (a), Au NPs/SPCE (b), aptamer/Au NPs/SPCE (c), MCH/ aptamer/Au NPs/SPCE (d) and PSA(1 ng/mL)/MCH/aptamer/Au NPs/SPCE (e) in $0.1 \mathrm{M} \mathrm{PBS} \mathrm{(pH=7.4)} \mathrm{containing}\left[\mathrm{Fe}(\mathrm{CN})_{6}\right]^{3-/ 4-} / \mathrm{KCl}(5 \mathrm{mM} / 0.1 \mathrm{M})$ electrolyte solution.

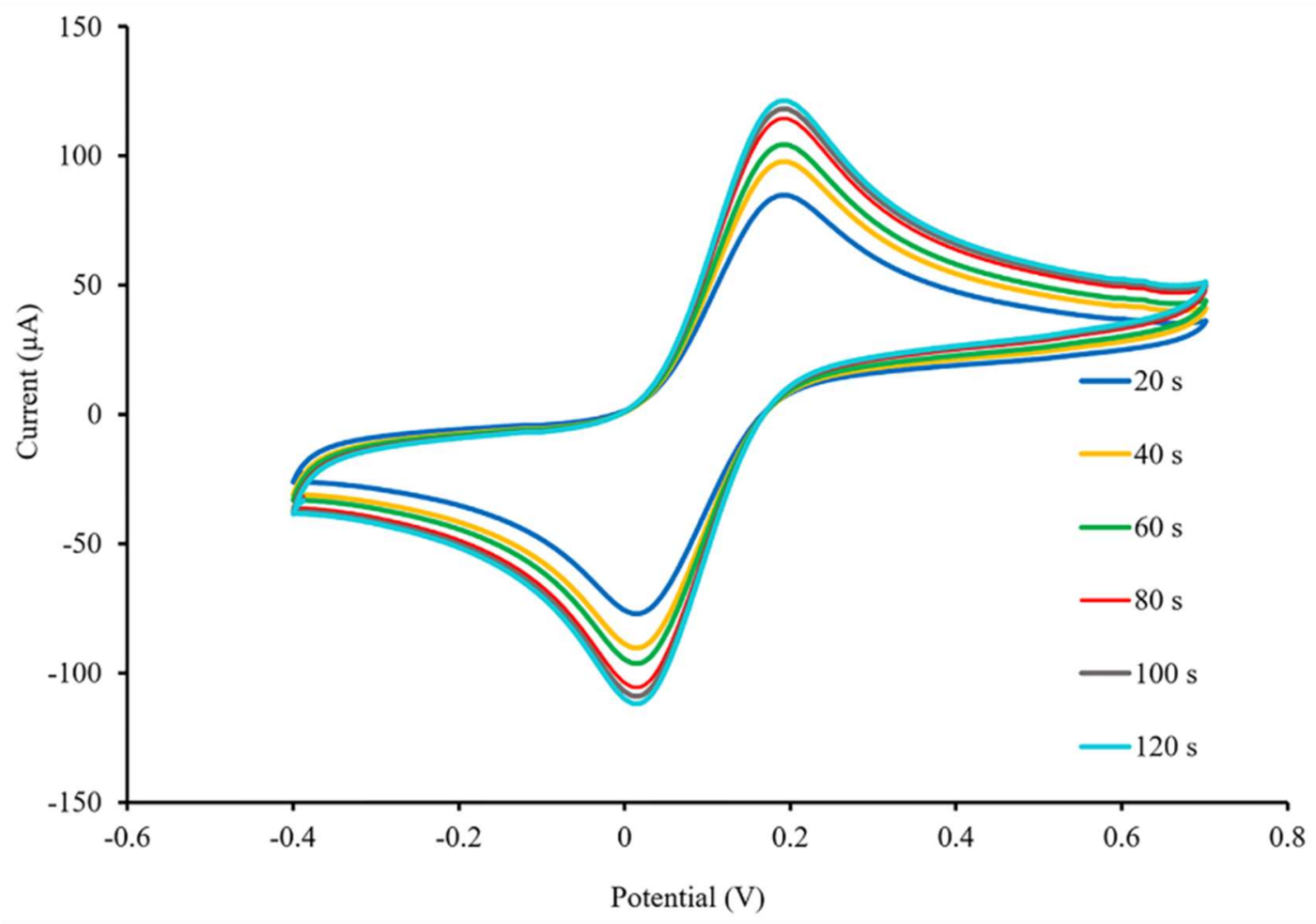

Figure 3. The CVs of SPCEs at different electrodeposition time of Au NPs on the electrode surface. 
The redox currents increases were directly proportional to the deposition time. Given the obtained CV records in a span of 20-120 s (Figure 4A), the optimal aptasensor state was found at the electrodeposition time of Au NPs SPCE of $80 \mathrm{~s}$.

The aptamer concentration is another contributing factor in the aptasensor responses. Thus different amounts $(10 \mu \mathrm{L}$ of $0.1-5 \mu \mathrm{M})$ of the thiolated aptamer were assessed to reach the maximum level of aptamerPSA interaction. According to the results, the current absolute value experienced a considerable rise before the aptamer concentration of $1 \mu \mathrm{M}$ and then remained approximately constant (Figure 4B). This may be because aptamers could be immobilized onto the SPCE surface with saturating binding attained at a concentration of $1 \mu \mathrm{M}$. The impact of incubation time on the self-assembly process was evaluated, testing multiple samples with different incubation periods ranging between 4 and $20 \mathrm{~h}$ (Figure 4C). According to
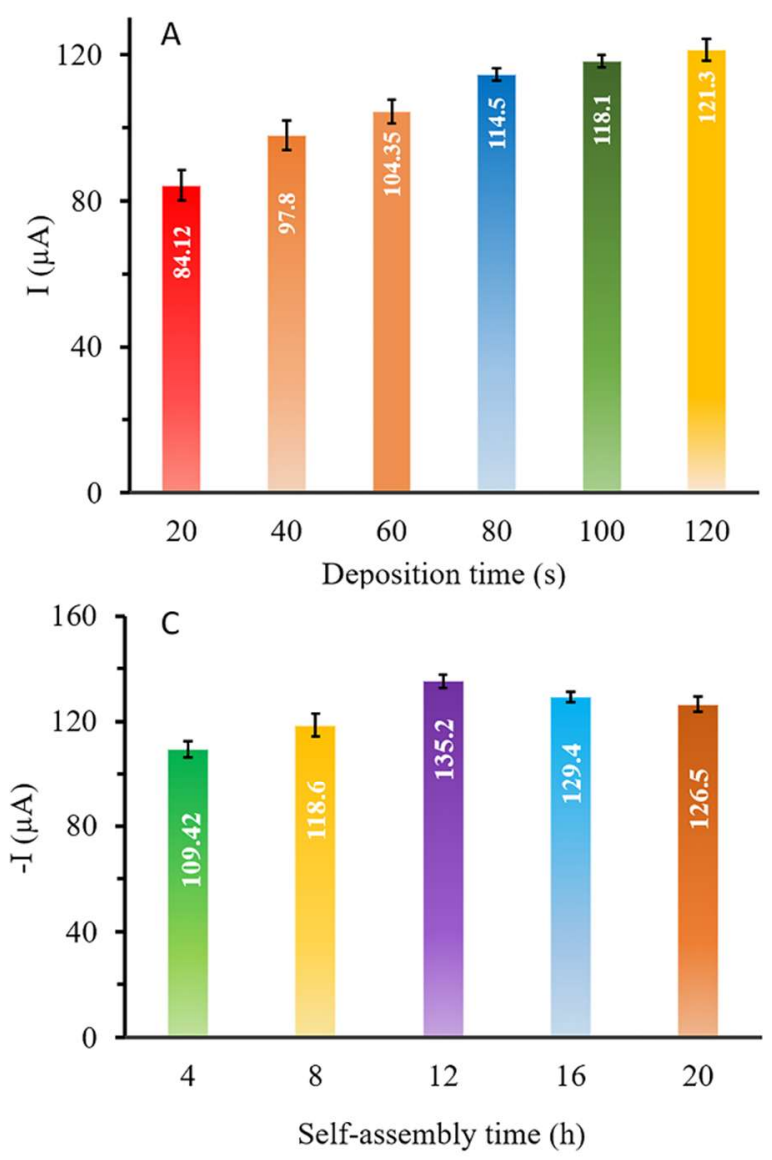

the DPV measurements, the maximum peak current was recorded in a sample incubated for $12 \mathrm{~h}$. Similar to the effect of aptamer concentration. It seemed that exceeding the time to more than $12 \mathrm{~h}$ resulted in the saturation of the active binding sites.

Moreover, a more extended incubation period led to the aggregation of aptamers, and the current absolute value gradually declined after this period. In addition to the self-assembly process, the effect of incubation time was evaluated on PSA/aptamer response following the addition of PSA solution (1 $\mathrm{ng} / \mathrm{mL})$ to the fabricated aptasensor (Figure 4D). In a period of $30-60 \mathrm{~min}$, the maximum peak current was observed at 45 min PSA incubation; after that, it reached a steady state, presumably caused by the saturation of aptamers.
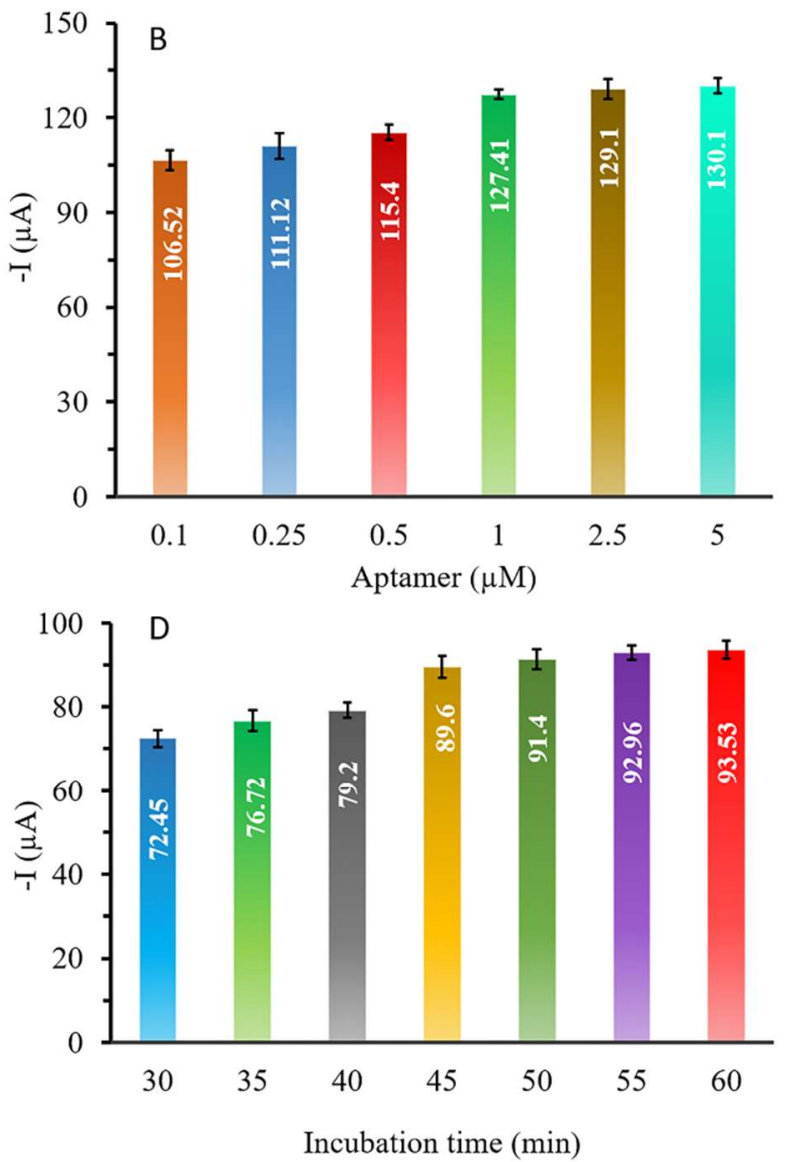

Figure 4. Optimization of the experimental parameters: effects of (A) electrodeposition time, (B) aptamer concentration, (C) self-assembly time, and (D) PSA incubation time. 


\section{EIS spectra of the modified electrode}

The EIS, as one of the vital electrochemical approaches, was implemented to assess the aptasensor condition in each step of the fabrication procedure. Impedance spectrum (Nyquist diagram) consists of two major compartments: a semicircle segment at high-frequency regions correlating to the chargetransfer resistance and a linear segment in the lowfrequency range corresponding to the diffusion process. The diameter of the semicircle stands for the charge-transfer resistance $\left(\mathrm{R}_{\mathrm{ct}}\right)$ at the electrode surface and the straight-line accounting for the diffusion resistance (40). The Randles equivalent circuit was employed to model the electrochemical impedance data (Figure 5, inset).

EIS data was recorded at a frequency ranging between $100 \mathrm{mHz}$ and $100 \mathrm{kHz}$ and an $\mathrm{AC}$ voltage amplitude of $0.01 \mathrm{~V}$, superimposed on a DC (direct current) of $+0.13 \quad \mathrm{~V}$. Figure 5 represents the Nyquist plots of impedance data of each modification step of the aptasensor in $0.1 \mathrm{M}$ PBS (pH
7.4) containing $\left[\mathrm{Fe}(\mathrm{CN})_{6}\right]^{3-/ 4-/} \mathrm{KCl}(5 \mathrm{mM} / 0.1 \mathrm{M})$ electrolyte solution.

Figure 5 curve a, corresponding to the impedance of the bare SPCE, indicates the $\mathrm{R}_{\mathrm{ct}}$ value of about 3167 $\Omega$ at the electrode surface. The electrodeposition of $\mathrm{Au}$ NPs on the working electrodes of bare SPCE resulted in a sharp reduction of the $\mathrm{R}_{\mathrm{ct}}$ level to $64 \Omega$ (Figure 5 , curve b). As previously confirmed by $\mathrm{CV}$, conductivity was considerably enhanced due to the expansion of the active surface area.

Subsequent immobilization of thiolated aptamer and MCH onto the Au NPs /SPCE caused the semicircle's diameter of the Nyquist plot to increase significantly. As a result of the blockade of charge transfer between SPCE and the redox probe, the $\mathrm{R}_{\mathrm{ct}}$ level rose from $2887 \Omega$ (Figure 5 , curve c) to $3646 \Omega$ (Figure 5, curve d).

Finally, the interaction between PSA and thiolated aptamer led to a noticeable rise in the amount of the $\mathrm{R}_{\mathrm{ct}}$ to $3976 \Omega$, indicating that the fabricated aptasensor interacted successfully with PSA (Figure 5, curve e).



Figure 5. Nyquist spectra of EIS data for intact SPCE (a), Au NPs/SPCE (b), aptamer/Au NPs/SPCE (c), MCH/aptamer/Au NPs/SPCE (d) and PSA(1 ng/mL)/MCH/aptamer/Au NPs/SPCE (e) in $0.1 \mathrm{M} \mathrm{PBS} \mathrm{(pH=7.4)} \mathrm{containing}\left[\mathrm{Fe}(\mathrm{CN})_{6}\right]^{3 / / 4-} / \mathrm{KCl}(5$ $\mathrm{mM} / 0.1 \mathrm{M})$ electrolyte solution. The Randles equivalent circuit was employed to model the electrochemical impedance data, $\left(R_{\mathrm{s}}\right.$ : solution resistance, $\mathrm{C}_{\mathrm{dl}}$ : double layer capacitance, $\mathrm{R}_{\mathrm{ct}}$ : charge transfer resistance, $\mathrm{W}$ : Warburg impedance). 


\section{PSA determination with the aptasensor}

Due to the higher sensitivity of the DPV technique compared to $\mathrm{CV}$, determination by DPV technique is recommended; besides, DPV can lower the background current (41). The quantitative determination of PSA was achieved by DPV signals in the same solution used for $\mathrm{CV}$ and under the optimal experimental conditions (potential range of +0.7 to $0.4 \mathrm{~V}$ interval time $=0.2 \mathrm{~s}$, modulation amplitude $=$ $0.05 \mathrm{~V})$. The aptasensor was incubated for $45 \mathrm{~min}$ in a various concentration of PSA in prepared in the PBS $0.1 \mathrm{M}(\mathrm{pH}=7.4)$ and eventually was detected a solution of $5 \mathrm{mM}\left[\mathrm{Fe}(\mathrm{CN})_{6}\right]^{3-/ 4-}$ containing $0.1 \mathrm{M} \mathrm{KCl}$ (pH 7.4). As depicted in Figure 6 A, the corresponding DPV peak current with increasing PSA concentrations is showing a significant decrease.

According to the results, a linear response was detected between cathodic peak current and logarithmic concentration of PSA ranging between 1 $\mathrm{pg} / \mathrm{mL}$ and $200 \mathrm{ng} / \mathrm{mL}$. Figure $6 \mathrm{~B}$ shows the performance of the aptasensor at different PSA concentrations by DPV. The limit of detection (LOD) was calculated to be $0.077 \mathrm{pg} / \mathrm{mL}(\mathrm{LOD}=3 \mathrm{Sb} / \mathrm{m}, \mathrm{Sb}$ : standard deviation of the blank, m: slope of the calibration curve) using the linear regression equation $\Delta \mathrm{I}(\mu \mathrm{A})=14.383 \log \mathrm{C}_{\mathrm{PSA}}(\mathrm{pg} / \mathrm{mL})+22.695$ and correlation coefficient of 0.992 .

Table 2 represents a brief overview of the analytical properties, LOD, and linear range of our novel aptasensor and the available assays for PSA determination. In summary, the LOD and linear range of our technique are comparable and even better than available published assays. Regarding its dominant characteristics, such as user-friendliness and inexpensiveness, our novel method introduces itself as a compelling alternative to the available traditional techniques.

When examined on three distinct modified SPCEs, the DPV method demonstrated that PSA (1 $\mathrm{ng} / \mathrm{mL}$ ) was measured with an acceptable relative standard deviation (RSD) value of $3.2 \%$, which certified that the test was reproducible under the experimental condition. Also, intra-and inter-day accuracy and precision (low, middle, and high standard concentrations) data for the determination of PSA are summarized in Table 3.

The stability of the fabricated aptasensor was investigated using three SPCEs kept at $4^{\circ} \mathrm{C}$ for 30 days. According to the results acquired from conventional assays (every five days) in this period, the response value experienced less than a $10 \%$ decline compared with the initial response, which was not statistically significant. This indicates that no considerable decomposition occurred, and fabricated biosensor remained perfectly stable in long-term storage.

\section{Selectivity}

The selectivity of aptasensors plays a decisive role in the acquisition of the quality to detect and quantify analyte of interest in real samples. To evaluate the selectivity of the aptasensor, the determination of both types of PSA concentration (including $100 \mathrm{pg} \mathrm{mL}^{-1}$ PSA1 and $10 \mathrm{pg} \mathrm{mL}^{-1}$ PSA2) was examined in the presence of different proteins. The selected proteins to do so were BSA, IgG, and hemoglobin, and the reason behind selecting them was their abundance in plasma. For this purpose, the aptasensor was firstly incubated for $45 \mathrm{~min}$ at $25^{\circ} \mathrm{C}$ with $200 \mathrm{pg} / \mathrm{mL}$ of each antigen (except for the PSA concentrations of 10 and 100 $\mathrm{pg} / \mathrm{mL}$ ) and DPV values were measured subsequently. Next, each stage was tested in two types of samples, one with all the antigens and only PSA1 and the other containing all the antigens and PSA 2. According to the results, the signals obtained from samples 1 and 2 did not show any significant differences with PSA1 and PSA2 sample's data and unsubstantial responses of the interfering compounds could be related to the negligible affinity of the fabricated aptasensor and its strong specificity for PSA (Figure 7).

\section{Quantitative assay of clinical serum samples}

To further investigate the functionality of our aptasensor for clinical applications, human serum samples obtained from Firoozgar Hospital were analyzed without any specific preparations or dilutions. The results corroborated our electrochemical analyses regarding the selectivity and specificity of the fabricated biosensor. Aptamer based$\mathrm{Au}$ NPs/SPCE records were strictly comparable to the reference values obtained by the ELISA method (Sigma-Aldrich, Germany), which was performed in the hospital as a standard method. As indicated in Figure $8 \mathrm{~A}$, the linear calibration curve was obtained by DPV (for eight samples with known PSA concentration ranging between $2.38 \mathrm{ng} / \mathrm{mL}$ and 92.26 $\mathrm{ng} / \mathrm{mL})$. The regression equation and correlation coefficient of the aptasensor in the presence of real samples were $\Delta \mathrm{I} \quad(\mu \mathrm{A})=23.697 \quad \log \quad \mathrm{C}_{\mathrm{PSA}}$ $(\mathrm{ng} / \mathrm{mL})+70.948$ and $\mathrm{R}^{2}=0.975$, respectively (Figure $8 \mathrm{~B}$ ). Table 4 shows the results of two analytical methods and their relative error which was calculated at $6.86 \%$. 

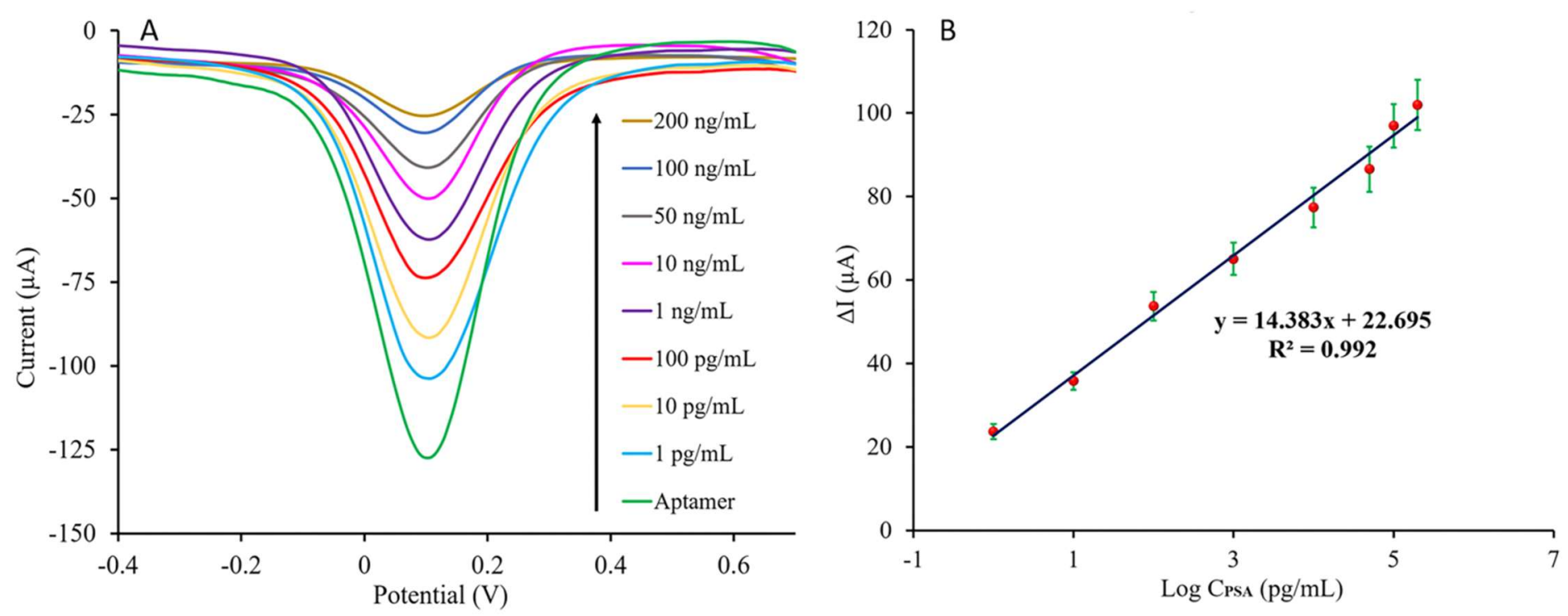

Figure 6. (A) DPV peaks of the fabricated aptasensor with different concentrations of PSA [0, 1, 10, 100 pg/mL, 1, 10, 50, 100, $200 \mathrm{ng} / \mathrm{mL}]$ in $0.1 \mathrm{M}$ PBS $(\mathrm{pH}=7.4)$ containing $\left[\mathrm{Fe}(\mathrm{CN})_{6}\right]^{3-/ 4-} / \mathrm{KCl}(5 \mathrm{mM} / 0.1 \mathrm{M})$ electrolyte solution. (B) PSA standard calibration curve in PBS $(0.1 \mathrm{M})$, the error bars represent the standard deviation of three consecutive measurements.

Table 2. Performance comparison of the present aptasensor and other techniques for PSA determination.

\begin{tabular}{|c|c|c|c|c|}
\hline Method & Recognition element & Linear range & LOD & References \\
\hline $\begin{array}{l}\text { Colorimetric } \\
\text { aptasensor }\end{array}$ & PolyA Apt/AuNPs & $0.1-100 \mathrm{ng} \mathrm{mL}^{-1}$ & $20 \mathrm{pg} \mathrm{mL}^{-1}$ & 42 \\
\hline $\begin{array}{l}\text { Fluorometric } \\
\text { aptasensor }\end{array}$ & EATR & $0.05-150 \mathrm{pg} \mathrm{mL}^{-1}$ & $0.043 \mathrm{pg} \mathrm{mL}^{-1}$ & 44 \\
\hline $\begin{array}{l}\text { Voltammetric } \\
\text { immunosensor }\end{array}$ & GO/AgNPs & $0.75-100 \mathrm{ng} \mathrm{mL}^{-1}$ & $0.27 \mathrm{ng} \mathrm{mL}^{-1}$ & 45 \\
\hline $\begin{array}{l}\text { Colorimetric } \\
\text { immunosensor }\end{array}$ & $\begin{array}{l}\mathrm{Fe}_{3} \mathrm{O}_{4}-\mathrm{Ab}_{2}-(\mathrm{PSA})-\mathrm{Ab}_{1}-\mathrm{Au} \\
\mathrm{NPs}\end{array}$ & $0.01-20 \mathrm{ng} \mathrm{mL}^{-1}$ & $9 \mathrm{pg} \mathrm{mL}^{-1}$ & 46 \\
\hline $\begin{array}{l}\text { Electrochemical } \\
\text { impedance } \\
\text { spectroscopy }\end{array}$ & $\begin{array}{l}\mathrm{Au} \mathrm{NPs} / \mathrm{C}_{60}-\mathrm{CS}-\mathrm{IL} / \\
\mathrm{MWCNTs}\end{array}$ & $1-200 \mathrm{pg} \mathrm{mL}^{-1}$ & $0.5 \mathrm{pg} \mathrm{mL}^{-1}$ & 39 \\
\hline $\begin{array}{l}\text { Chemiluminescent } \\
\text { dual-aptasensor }\end{array}$ & $\begin{array}{l}\text { Guanine chemiluminescence } \\
\text { - CRET }\end{array}$ & $1.9-125 \mathrm{ng} \mathrm{mL}^{-1}$ & $1 \mathrm{ng} \mathrm{mL}^{-1}$ & 12 \\
\hline $\begin{array}{l}\text { Dual-modality } \\
\text { impedimetric } \\
\text { immunosensor }\end{array}$ & $\begin{array}{l}\text { Antibody-molecularly } \\
\text { imprinted polymer }\end{array}$ & $\begin{array}{l}0.01-100 \mathrm{ng} \mathrm{mL}^{-1} \\
\text { and } 1-20000 \mathrm{ng} \mathrm{mL}^{-1}\end{array}$ & $\begin{array}{l}5.4 \mathrm{pg} \mathrm{mL}^{-1} \\
\text { and } 0.83 \mathrm{ng} \mathrm{mL}^{-1}\end{array}$ & 48 \\
\hline
\end{tabular}




\begin{tabular}{|c|c|c|c|c|}
\hline $\begin{array}{l}\text { Optical aptasensor } \\
\text { (Fluorescent) }\end{array}$ & $\begin{array}{l}\text { Tb-MOFs/Au NPs } \\
\text { Platform }\end{array}$ & $1-100 \mathrm{ng} \mathrm{mL}^{-1}$ & $0.36 \mathrm{ng} \mathrm{mL}^{-1}$ & 49 \\
\hline $\begin{array}{l}\text { Optical aptasensor } \\
\text { (Light scattering) }\end{array}$ & $\begin{array}{l}\text { Target stimuli-responsive } \\
\text { assembly of Au NPs }\end{array}$ & $10-20000 \mathrm{pg} \mathrm{mL}^{-1}$ & $2 \mathrm{pg} \mathrm{mL}^{-1}$ & 50 \\
\hline $\begin{array}{l}\text { Electrochemical } \\
\text { aptasensor }\end{array}$ & $\begin{array}{l}\text { Label-free PSA aptasensor } \\
\text { and PSA immunosensor } \\
\text { based on GQD/Au NRs }\end{array}$ & $0.4-11.6 \mathrm{ng} \mathrm{mL}^{-1}$ & $140 \mathrm{pg} \mathrm{mL}^{-1}$ & 4 \\
\hline $\begin{array}{l}\text { Fluorescence } \\
\text { biosensor }\end{array}$ & $\begin{array}{l}\text { Peptide- } \mathrm{Fe}_{3} \mathrm{O}_{4} @ \mathrm{SiO}_{2}-\mathrm{Au} \\
\text { nanocomposite }\end{array}$ & $0.001-1 \mathrm{ng} \mathrm{mL} L^{-1}$ & $0.3 \mathrm{ng} \mathrm{mL}^{-1}$ & 51 \\
\hline $\begin{array}{l}\text { Electrochemical } \\
\text { aptasensor }\end{array}$ & $\begin{array}{l}\text { Thiolated label- free } \\
\text { Aptamer/Au NPs }\end{array}$ & $1 \mathrm{pg} \mathrm{mL}^{-1}-200 \mathrm{ng} \mathrm{mL}^{-1}$ & $0.077 \mathrm{pg} \mathrm{mL}^{-1}$ & Present study \\
\hline \multicolumn{5}{|c|}{$\begin{array}{l}\text { Abbreviations: PolyA Apt/Au NPs, poly-Adenine aptamer/gold nanoparticles; QDs/MOFs, quantum dots/magnetic metal- } \\
\text { organic frameworks; EATR, enzyme-assisted target recycling; GO/Ag NPs, graphene oxide/ silver nanoparticles; Au NPs/C60- } \\
\text { CS-IL/MWCNTs, Au nanoparticles/fullerene } \quad \mathrm{C}_{60} \text {-chitosan-ionic liquid/multi-walled carbon nanotubes; CRET, } \\
\text { Chemiluminescence resonance energy transfer; GQD/Au NRs, graphene quantum dots/gold nanorods. }\end{array}$} \\
\hline
\end{tabular}

Table 3. Intra -and inter-day precision of the electrochemical aptasensor method for the determination of PSA.

\begin{tabular}{|c|c|c|c|c|c|c|c|c|}
\hline \multirow{2}{*}{$\begin{array}{c}\text { Concentration } \\
(\mathrm{ng} / \mathrm{mL})\end{array}$} & \multicolumn{2}{|c|}{ Raw data } & \multicolumn{3}{|c|}{ Intra-day $(n=3)$} & \multicolumn{3}{|c|}{ Inter-day $(\mathrm{n}=3)$} \\
\hline & Intra-day & Inter-day & Mean & SD & CV\% & Mean & SD & CV\% \\
\hline \multirow{4}{*}{0.001} & $\Delta \mathbf{I}(\boldsymbol{\mu} \mathbf{A})$ & $\Delta \mathbf{I}(\boldsymbol{\mu} \mathbf{A})$ & \multirow{4}{*}{23.09} & \multirow{4}{*}{0.580} & \multirow{4}{*}{2.51} & \multirow{4}{*}{22.92} & \multirow{4}{*}{0.761} & \multirow{4}{*}{3.32} \\
\hline & 23.66 & 23.16 & & & & & & \\
\hline & 22.50 & 22.47 & & & & & & \\
\hline & 23.12 & 22.14 & & & & & & \\
\hline \multirow{4}{*}{1} & $\Delta \mathbf{I}(\boldsymbol{\mu} \mathbf{A})$ & $\Delta \mathbf{I}(\boldsymbol{\mu} \mathbf{A})$ & \multirow{4}{*}{63.46} & \multirow{4}{*}{2.031} & \multirow{4}{*}{3.20} & \multirow{4}{*}{64.97} & \multirow{4}{*}{2.861} & \multirow{4}{*}{4.12} \\
\hline & 65.07 & 65.87 & & & & & & \\
\hline & 61.18 & 62.24 & & & & & & \\
\hline & 64.14 & 68.4 & & & & & & \\
\hline \multirow{4}{*}{100} & $\Delta \mathbf{I}(\mu \mathbf{A})$ & $\Delta \mathbf{I}(\boldsymbol{\mu} \mathbf{A})$ & \multirow{4}{*}{95.92} & \multirow{4}{*}{5.35} & \multirow{4}{*}{5.57} & \multirow{4}{*}{94.88} & \multirow{4}{*}{5.872} & \multirow{4}{*}{6.18} \\
\hline & 96.92 & 95.82 & & & & & & \\
\hline & 90.14 & 88.26 & & & & & & \\
\hline & 100.7 & 98.36 & & & & & & \\
\hline
\end{tabular}




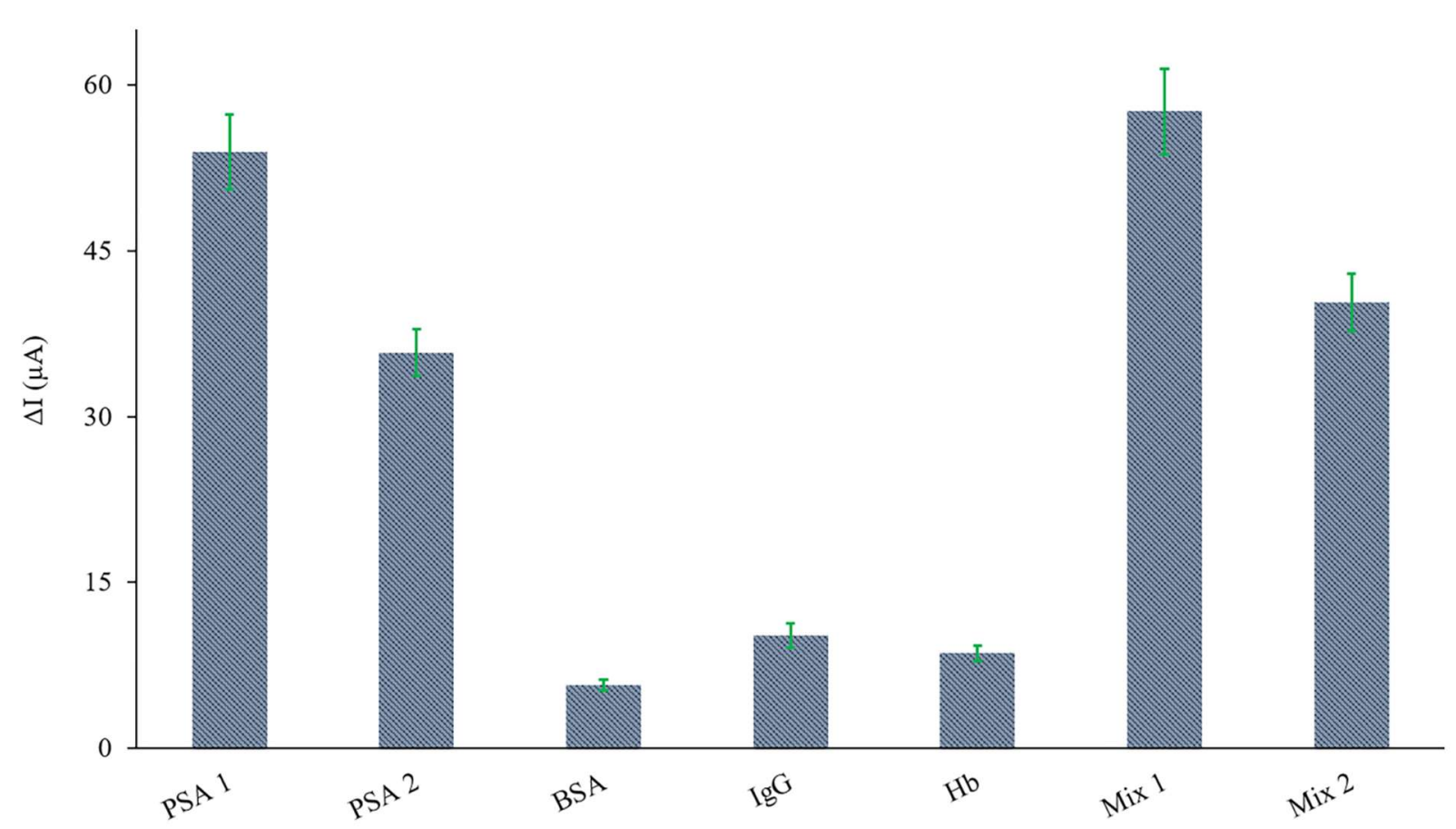

Figure 7. Comparison of current change of the PSA-aptasensor by incubated in $100 \mathrm{pg} \mathrm{mL}^{-1} \mathrm{PSA}, 10 \mathrm{pg} \mathrm{mL}^{-1} \mathrm{PSA}_{2}$, and

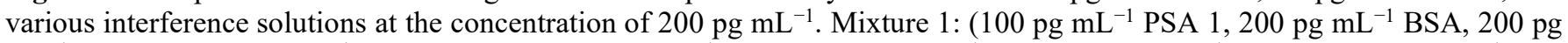

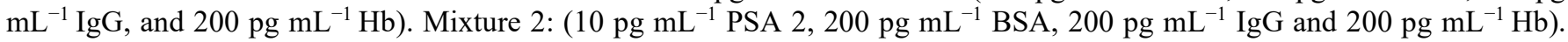
Error bars show the standard deviations of three independent measurements.
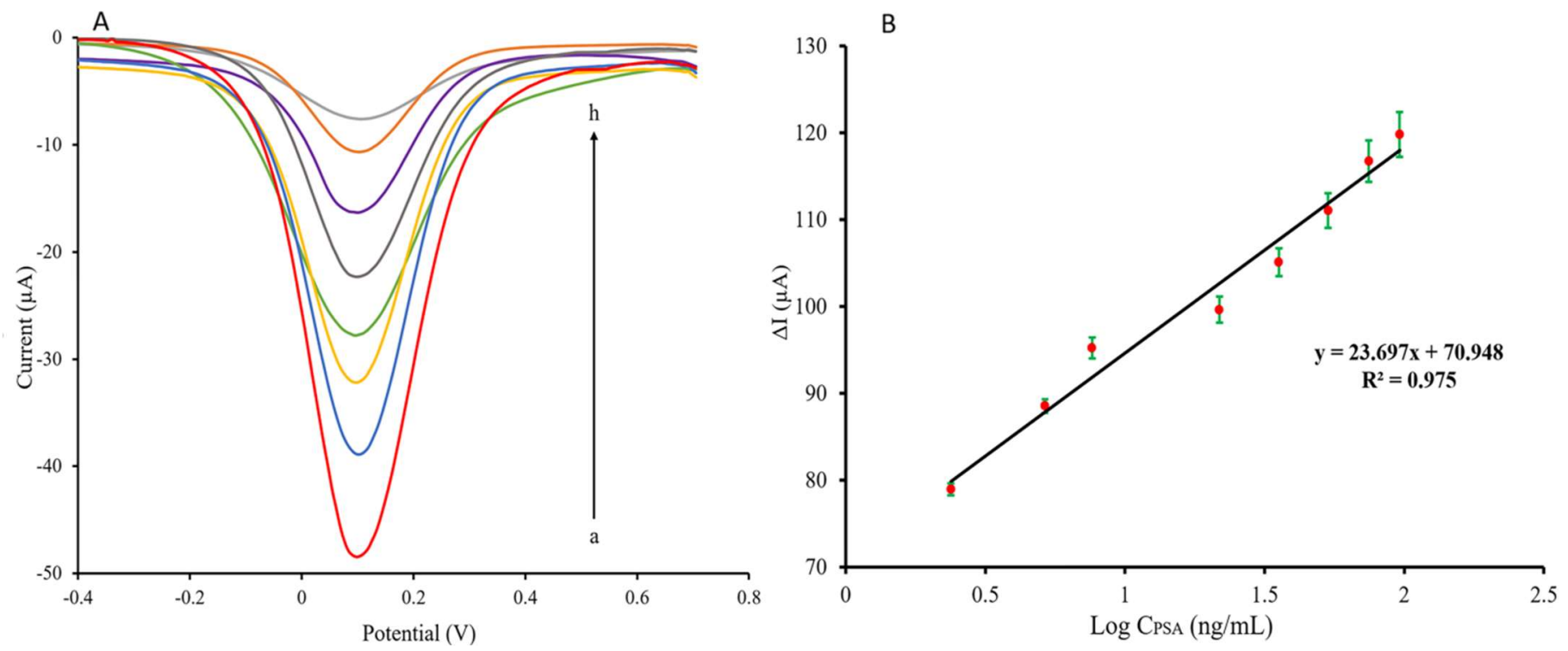

Figure 8. (A) DPV measurements of the aptasensor interacted with different clinical serum samples and (B) the standard calibration curve. The error bars indicate the standard deviation of triplicate analysis. 
Table 4. Determination of PSA in clinical serum samples and comparison to the reference method (ELISA)

\begin{tabular}{|c|c|c|c|}
\hline Sample & $\begin{array}{l}\text { Reference method } \\
\left(\text { (ng mL } L^{-1}\right)\end{array}$ & $\begin{array}{c}\text { Aptasensor } \\
\left(\mathrm{ng} \mathrm{mL^{-1 }}\right)\end{array}$ & $\begin{array}{c}\text { Relative errors } \\
(\%)\end{array}$ \\
\hline 1 & 1.34 & 1.27 & -5.22 \\
\hline 2 & 2.72 & 2.80 & 2.94 \\
\hline 3 & 4.80 & 5.02 & 4.58 \\
\hline 4 & 6.12 & 6.54 & 6.86 \\
\hline 5 & 8.04 & 7.80 & -2.98 \\
\hline 6 & 10.60 & 10.12 & -4.52 \\
\hline 7 & 12.51 & 11.82 & -5.51 \\
\hline 8 & 14.13 & 13.85 & -1.98 \\
\hline 9 & 21.73 & 22.40 & 3.08 \\
\hline 10 & 51.46 & 50.15 & -2.54 \\
\hline
\end{tabular}

\section{CONCLUSION}

In summary, a novel aptasensor was fabricated for precise determination of PSA biomarker based on the immobilization of thiol terminated PSA binding DNA aptamers onto Au NPs/ SPCEs. Surface modification performed by gold nanoparticles offered a highly efficient electrode for aptamer immobilization. The superb conductivity of Au NPs modified SPCEs ensured an effective charge transfer at the interface between the electrodes and the aptamer receptor. Regarding the substantial features of electrochemical transducers such as adaptability, simplicity, and swiftness, the biosensing technique can be much efficient. The fabricated biosensor in this study benefiting from distinguishing features of aptamerbased techniques (instead of antibodies) and nanoparticle-based signal amplification offers a viable option for prostate cancer screening. Under the optimum condition, our EC aptasensor is capable of detecting PSA levels as small as $0.077 \mathrm{pg} / \mathrm{mL}$ in a linear response range from $1 \mathrm{pg} / \mathrm{mL}$ to $200 \mathrm{ng} / \mathrm{mL}$. Serum sample analyses demonstrated that our aptasensor could determine the amount of PSA as accurately as the reference method (ELISA). Therefore, it would be a credible and economical alternative to the conventional analyzing method for point-of-care testing (POCT) of prostate cancer. However, biosensor designing is one of the innovative methods used in the field of biotechnology to detect sensitively various types of biomarkers. It is noteworthy to say that this low limit of detection is a research goal, and it is not necessarily for clinical applications.

Additionally, further modifications could be applied to the SPCE to boost its performance and enable the aptasensor to detect multiple biomarkers simultaneously. This would be a promising strategy for an accurate determination that could be exploited in various types of diseases. Preparation of a conventional sensitive aptamer-based biosensor kit for electrochemical quantification of PSA in routine check-up and screening of prostate problems in the men is suggested.

\section{HIGHLIGHTS}

A novel strategy for electrochemical determination of PSA based on the aptamer/Au NPs modified SPCE was introduced.

The fabricated aptasensor was validated by comparison to the reference method (ELISA) for PSA determination in clinical serum samples.

A Label-free aptamer-based biosensor offers a straightforward, rapid, ultrasensitive, and selective method for the determination of PSA.

\section{ACKNOWLEDGMENT}

The work was supported by a grant from Tehran University of Medical Sciences (Code Number: 9802-222-42563). Iran National Science Foundation is 
acknowledged for the Seat Award directed to the corresponding author.

\section{AUTHOR CONTRIBUTION}

All authors made substantial contributions to conception and design, acquisition of data, or analysis and interpretation of data; took part in drafting the article or revising it critically for relevant intellectual content; gave final approval of the version to be published; and agreed to be accountable for all aspects of the work.

\section{CONFLICT OF INTEREST}

The authors report no conflicts of interest in this work.

\section{REFERENCES}

1. Siegel RL, Miller KD, Jemal A. Cancer statistics, 2019. CA: a cancer journal for clinicians. 2019;69(1):7-34. https://doi.org/10.3322/caac.21551

2. Rawla P. Epidemiology of prostate cancer. World journal of oncology. 2019;10(2):63. https://doi.org/10.14740/wjon1191

3. Chang Y, Wang M, Wang L, Xia N. Recent progress in electrochemical biosensors for detection of prostatespecific antigen. Int J Electrochem Sci. 2018;13:407184. https://www.doi.org/10.20964/2018.05.24

4. Srivastava M, Nirala NR, Srivastava S, Prakash R. A comparative study of aptasensor vs immunosensor for label-free PSA cancer detection on GQDs-AuNRs modified screen-printed electrodes. Scientific reports. 2018;8(1):1-11. https://doi.org/10.1038/s41598-01819733-z

5. Mottet N, Bellmunt J, Bolla M, Briers E, Cumberbatch MG, De Santis M, et al. EAU-ESTRO-SIOG guidelines on prostate cancer. Part 1: screening, diagnosis, and local treatment with curative intent. European urology. 2017;71(4):618-29.

https://doi.org/10.1016/j.eururo.2016.08.003

6. Sharipov M, Azizov S, Kakhkhorov S, Yunuskhodjaev A, Lee Y-I. Emerging spectroscopic techniques for prostate cancer diagnosis. Applied Spectroscopy Reviews. 2019;54(10):829-55. https://doi.org/10.1080/05704928.2018.1481864

7. Chen M, Ma C, Yan Y, Zhao H. A label-free fluorescence method based on terminal deoxynucleotidyl transferase and thioflavin $\mathrm{T}$ for detecting prostate-specific antigen. Analytical and bioanalytical chemistry. 2019;411(22):5779-84. https://doi.org/10.1007/s00216-019-01958-0

8. Salminen T, Juntunen E, Talha SM, Pettersson K. High-sensitivity lateral flow immunoassay with a fluorescent lanthanide nanoparticle label. Journal of immunological methods. 2019;465:39-44. https://doi.org/10.1016/j.jim.2018.12.001

9. Yoo J, Jung YM, Hahn JH, Pyo D. Quantitative analysis of a prostate-specific antigen in serum using fluorescence immunochromatography. Journal of immunoassay \& immunochemistry. 2010;31(4):25965. https://doi.org/10.1080/15321819.2010.524855

10. Jiang Z, Qin Y, Peng Z, Chen S, Chen S, Deng C, et al. The simultaneous detection of free and total prostate antigen in serum samples with high sensitivity and specificity by using the dual-channel surface plasmon resonance. Biosensors \& bioelectronics. 2014;62:26873. https://doi.org/10.1016/j.bios.2014.06.060

11. Chen N, Rong M, Shao X, Zhang H, Liu S, Dong B, et al. Surface-enhanced Raman spectroscopy of serum accurately detects prostate cancer in patients with prostate-specific antigen levels of $4-10 \mathrm{ng} / \mathrm{mL}$. International journal of nanomedicine. 2017;12:5399. https://doi.org/10.2147/ijn.s137756

12. Chong J, Chong H, Lee JH. A chemiluminescent dualaptasensor capable of simultaneously quantifying prostate specific antigen and vascular endothelial growth factor. Analytical biochemistry. 2019;564:1027. https://doi.org/10.1016/j.ab.2018.10.024

13. Yang C, Guo Q, Lu Y, Zhang B, Nie G. Ultrasensitive "signal-on" electrochemiluminescence immunosensor for prostate-specific antigen detection based on novel nanoprobe and poly (indole-6-carboxylic acid)/flowerlike $\mathrm{Au}$ nanocomposite. Sensors and Actuators B: Chemical. 2020;303:127246. https://doi.org/10.1016/j.snb.2019.127246

14. Klee EW, Bondar OP, Goodmanson MK, Trushin SA, Singh RJ, Anderson NL, et al. Mass spectrometry measurements of prostate-specific antigen (PSA) peptides derived from immune-extracted PSA provide a potential strategy for harmonizing immunoassay differences. American journal of clinical pathology. 2014;141(4):527-33. https://doi.org/10.1309/ajcp8pel0yxahdvk

15. Traynor SM, Pandey R, Maclachlan R, Hosseini A, Didar TF, Li F, et al. Recent Advances in Electrochemical Detection of Prostate Specific Antigen (PSA) in Clinically-Relevant Samples. Journal of The Electrochemical Society. 2020;167(3):037551. https://doi.org/10.1149/1945-7111/ab69fd

16. Negahdary M, Sattarahmady N, Heli H. Advances in prostate specific antigen biosensors-impact of nanotechnology. Clinica chimica acta; international journal of clinical chemistry. 2020;504:43-55. https://doi.org/10.1016/j.cca.2020.01.028

17. Argoubi W, Sanchez A, Parrado C, Raouafi N, Villalonga R. Label-free electrochemical aptasensing platform based on mesoporous silica thin film for the detection of prostate specific antigen. Sensors and Actuators B: Chemical. 2018;255:309-15. https://doi.org/10.1016/j.snb.2017.08.045 
18. Hosseini S, Vázquez-Villegas $\mathrm{P}$, Rito-Palomares $\mathrm{M}$, Martinez-Chapa SO. Advantages, Disadvantages and Modifications of Conventional ELISA. Enzymelinked Immunosorbent Assay (ELISA): Springer; 2018. p. 67-115. https://doi.org/10.1007/978-981-106766-2 5

19. Maghsoudi AS, Hassani S, Akmal MR, Ganjali MR, Mirnia K, Norouzi P, et al. An Electrochemical Aptasensor Platform Based on Flower-Like Gold Microstructure-Modified Screen-Printed Carbon Electrode for Detection of Serpin A12 as a Type 2 Diabetes Biomarker. International Journal of Nanomedicine. 2020;15:2219. https://doi.org/10.2147/ijn.s244315

20. Röthlisberger P, Hollenstein M. Aptamer chemistry. Advanced drug delivery reviews. 2018;134:3-21. https://doi.org/10.1016/j.addr.2018.04.007

21. Salek-Maghsoudi A, Vakhshiteh F, Torabi R, Hassani $\mathrm{S}$, Ganjali MR, Norouzi $\mathrm{P}$, et al. Recent advances in biosensor technology in assessment of early diabetes biomarkers. Biosensors and Bioelectronics. 2018;99:122-35.

https://doi.org/10.1016/j.bios.2017.07.047

22. Yoon S, Rossi JJ. Aptamers: Uptake mechanisms and intracellular applications. Advanced drug delivery reviews. 2018;134:22-35. https://doi.org/10.1016/j.addr.2018.07.003

23. Wei B, Mao K, Liu N, Zhang M, Yang Z. Graphene nanocomposites modified electrochemical aptamer sensor for rapid and highly sensitive detection of prostate specific antigen. Biosensors and Bioelectronics. 2018;121:41-6. https://doi.org/10.1016/j.bios.2018.08.067

24. Villalonga A, Pérez-Calabuig AM, Villalonga R. Electrochemical biosensors based on nucleic acid aptamers. Analytical and bioanalytical chemistry. 2020:1-18. https://doi.org/10.1007/s00216-019-02226$\mathrm{x}$

25. Jolly P, Formisano N, Estrela P. DNA aptamer-based detection of prostate cancer. Chemical Papers. 2015;69(1):77-89. http://dx.doi.org/10.1515/chempap2015-0025

26. Mehrotra P. Biosensors and their applications-A review. Journal of oral biology and craniofacial research. 2016;6(2):153-9. https://doi.org/10.1016/j.jobcr.2015.12.002

27. Hassani S, Momtaz S, Vakhshiteh F, Maghsoudi AS, Ganjali MR, Norouzi P, et al. Biosensors and their applications in detection of organophosphorus pesticides in the environment. Archives of toxicology. 2017;91(1):109-30. https://doi.org/10.1007/s00204016-1875-8

28. Kuo YC, Lee CK, Lin CT. Improving sensitivity of a miniaturized label-free electrochemical biosensor using zigzag electrodes. Biosensors \& bioelectronics. 2018;103:130-7.

https://doi.org/10.1016/j.bios.2017.11.065
29. Yamanaka K, Vestergaard MC, Tamiya E. Printable Electrochemical Biosensors: A Focus on ScreenPrinted Electrodes and Their Application. Sensors (Basel, Switzerland). 2016;16(10). https://doi.org/10.3390/s16101761

30. Hassani S, Akmal MR, Salek-Maghsoudi A, Rahmani S, Ganjali MR, Norouzi P, et al. Novel label-free electrochemical aptasensor for determination of Diazinon using gold nanoparticles-modified screenprinted gold electrode. Biosensors and Bioelectronics. 2018;120:122-8. https://doi.org/10.1016/j.bios.2018.08.041

31. Savory N, Abe K, Sode K, Ikebukuro K. Selection of DNA aptamer against prostate specific antigen using a genetic algorithm and application to sensing. Biosensors \& bioelectronics. 2010;26(4):1386-91. https://doi.org/10.1016/j.bios.2010.07.057

32. Fang B-Y, Wang C-Y, Li C, Wang H-B, Zhao Y-D. Amplified using DNase I and aptamer/graphene oxide for sensing prostate specific antigen in human serum. Sensors and Actuators B: Chemical. 2017;244:928-33. http://dx.doi.org/10.1016/2Fj.snb.2017.01.045

33. Jiang $\mathrm{P}$, Wang $\mathrm{Y}$, Zhao L, Ji C, Chen D, Nie L. Applications of gold nanoparticles in non-optical biosensors. Nanomaterials. 2018;8(12):977. https://doi.org/10.1016/j.snb.2017.01.045

34. Jolly P, Tamboli V, Harniman RL, Estrela P, Allender CJ, Bowen JL. Aptamer-MIP hybrid receptor for highly sensitive electrochemical detection of prostate specific antigen. Biosensors and Bioelectronics. 2016;75:188-95. https://doi.org/10.1016/j.bios.2015.08.043

35. Stine KJ. Biosensor applications of electrodeposited nanostructures. Applied Sciences. 2019;9(4):797. https://doi.org/10.3390/app9040797

36. Wan H, Sun Q, Li H, Sun F, Hu N, Wang P. Screenprinted gold electrode with gold nanoparticles modification for simultaneous electrochemical determination of lead and copper. Sensors and Actuators B: Chemical. 2015;209:336-42. https://doi.org/10.1016/j.snb.2014.11.127

37. Fan L, Zhao G, Shi H, Liu M, Li Z. A highly selective electrochemical impedance spectroscopy-based aptasensor for sensitive detection of acetamiprid. Biosensors and Bioelectronics. 2013;43:12-8. https://doi.org/10.1016/j.bios.2012.11.033

38. Arduini F, Micheli L, Moscone D, Palleschi G, Piermarini S, Ricci F, et al. Electrochemical biosensors based on nanomodified screen-printed electrodes: Recent applications in clinical analysis. TrAC Trends in Analytical Chemistry. 2016;79:114-26. https://doi.org/10.1016/j.trac.2016.01.032

39. Jalalvand AR. Fabrication of a novel and ultrasensitive label-free electrochemical aptasensor for detection of biomarker prostate specific antigen. International journal of biological macromolecules. 2019;126:106573. https://doi.org/10.1016/j.ijbiomac.2019.01.012 
40. Han Y, Wang J, Zhang H, Zhao S, Ma Q, Wang Z. Electrochemical impedance spectroscopy (EIS): An efficiency method to monitor resin curing processes. Sensors and Actuators A: Physical. 2016;250:78-86. https://doi.org/10.1016/j.sna.2016.08.028

41. Burç M, Köytepe S, Duran ST, Ayhan N, Aksoy B, Seçkin T. Development of voltammetric sensor based on polyimide-MWCNT composite membrane for rapid and highly sensitive detection of paracetamol. Measurement. 2020;151:107103. https://doi.org/10.1016/j.measurement.2019.107103

42. Shayesteh OH, Ghavami R. A novel label-free colorimetric aptasensor for sensitive determination of PSA biomarker using gold nanoparticles and a cationic polymer in human serum. Spectrochimica Acta Part A: Molecular and Biomolecular Spectroscopy. 2020;226:117644. https://doi.org/10.1016/j.saa.2019.117644

43. Ehzari H, Amiri M, Safari M. Enzyme-free sandwichtype electrochemical immunosensor for highly sensitive prostate specific antigen based on conjugation of quantum dots and antibody on surface of modified glassy carbon electrode with core-shell magnetic metal-organic frameworks. Talanta. 2020;210:120641. https://doi.org/10.1016/j.talanta.2019.120641

44. Chen M, Tang Z, Ma C, Yan Y. A fluorometric aptamer based assay for prostate specific antigen based on enzyme-assisted target recycling. Sensors and Actuators B: Chemical. 2020;302:127178. https://doi.org/10.1016/j.snb.2019.127178

45. Thunkhamrak C, Chuntib P, Ounnunkad K, Banet P, Aubert P-H, Saianand G, et al. Highly sensitive voltammetric immunosensor for the detection of prostate specific antigen based on silver nanoprobe assisted graphene oxide modified screen printed carbon electrode. Talanta. 2020;208:120389. https://doi.org/10.1016/j.talanta.2019.120389

46. Karami P, Khoshsafar H, Johari-Ahar M, Arduini F, Afkhami A, Bagheri H. Colorimetric immunosensor for determination of prostate specific antigen using surface plasmon resonance band of colloidal triangular shape gold nanoparticles. Spectrochimica Acta Part A: Molecular and Biomolecular Spectroscopy. 2019;222:117218. https://doi.org/10.1016/j.saa.2019.117218

47. Yazdani Z, Yadegari H, Heli H. A molecularly imprinted electrochemical nanobiosensor for prostate specific antigen determination. Analytical biochemistry. 2019;566:116-25. https://doi.org/10.1016/j.ab.2018.11.020

48. Karami P, Bagheri H, Johari-Ahar M, Khoshsafar H, Arduini F, Afkhami A. Dual-modality impedimetric immunosensor for early detection of prostate-specific antigen and myoglobin markers based on antibodymolecularly imprinted polymer. Talanta. 2019;202:111-22.

https://doi.org/10.1016/j.talanta.2019.04.061
49. Qu F, Ding Y, Lv X, Xia L, You J, Han W. Emissions of terbium metal-organic frameworks modulated by dispersive/agglomerated gold nanoparticles for the construction of prostate-specific antigen biosensor. Analytical and bioanalytical chemistry. 2019;411(17):3979-88. https://doi.org/10.1007/s00216-019-01883-2

50. Liu G, Feng D-Q, Li Z, Feng Y. Target-activatable gold nanoparticle-based aptasensing for protein biomarkers using stimuli-responsive aggregation. Talanta. 2019;192:112-7. https://doi.org/10.1016/j.talanta.2018.08.034

51. Yang L, Li N, Wang K, Hai X, Liu J, Dang F. A novel peptide/Fe3O4@ SiO2-Au nanocomposite-based fluorescence biosensor for the highly selective and sensitive detection of prostate-specific antigen. Talanta. 2018;179:531-7. https://doi.org/10.1016/j.talanta.2017.11.033 